Article

\title{
Effects of Interfacial Reactions on Microstructures and Mechanical Properties of 3003 Al/T2 Cu and 1035 Al/T2 Cu Brazed Joints
}

\author{
Man Zhang \\ Faculty of Mechanical \& Material Engineering, Huaiyin Institute of Technology, Huai'an 223001, China; \\ 11050012@hyit.edu.cn
}

Received: 3 March 2020; Accepted: 25 March 2020; Published: 27 March 2020

\begin{abstract}
To meet the demand for efficient and reliable copper and aluminum $(\mathrm{Cu} / \mathrm{Al})$ joints in refrigeration and electric power industries, interfacial reactions in $3003 \mathrm{Al} / \mathrm{T} 2 \mathrm{Cu}$ and $1035 \mathrm{Al} / \mathrm{T} 2 \mathrm{Cu}$ joints brazed by $\mathrm{Zn}-\mathrm{xAl}$ ( $\mathrm{x}$ ranged from 2-25 wt.\%) filler metals and their effects on the mechanical properties of the joints were investigated. Microstructures and fracture surfaces were observed combining with composition analysis. For $3003 \mathrm{Al} / \mathrm{Cu}$ joints, bulk $\mathrm{CuAl}$ and $\mathrm{CuAl}_{2}$ intermetallic compound (IMC) formed in brazing seams, and a $\mathrm{CuAl}$ IMC layer formed at the $\mathrm{Cu}$ side interfaces. For $1035 \mathrm{Al} / \mathrm{Cu}$ joints, bulk $\mathrm{CuAl}_{2} \mathrm{IMC}$ formed in brazing seams, and an $\mathrm{Al}_{4.2} \mathrm{Cu}_{3.2} \mathrm{Zn}_{0.7} \mathrm{IMC}$ layer formed at the $\mathrm{Cu}$ side interfaces. For both kinds of joints, shear strength increased first, then decreased with the increasing $\mathrm{Al}$ content. The increase in shear strength was because $\mathrm{Al}$ promoted the formation of $\mathrm{Cu}-\mathrm{Al} \mathrm{IMC}$, and caused dispersion strengthening. With the excessive $\mathrm{Al}$ content, however, the bulk IMC became coarse and the IMC layers at $\mathrm{Cu}$ side interfaces grew thick, causing the joint strength to decrease due to stress concentration. The strength of $3003 \mathrm{Al} / \mathrm{Cu}$ joints was always higher than that of $1035 \mathrm{Al} / \mathrm{Cu}$, and their highest strength were achieved by $\mathrm{Zn}-12 \mathrm{Al}$ and $\mathrm{Zn}-15 \mathrm{Al}$, respectively.
\end{abstract}

Keywords: 3003 aluminum; 1035 aluminum; T2 Cu; brazing; interfacial reaction; mechanical property; microstructure

\section{Introduction}

Both copper $(\mathrm{Cu})$ and aluminum (Al) present high electrical conductivity, good thermal conductivity and excellent corrosion resistance [1]. $\mathrm{Cu} / \mathrm{Al}$ dissimilar joints combine the advantages of $\mathrm{Cu}$ and $\mathrm{Al}[2-4]$, and therefore are widely used in the industries that require not only excellent electrical and thermal conductivity, but also weight and cost reduction, such as refrigeration, electric power and automobiles, etc. [5-8]. Excessive brittle $\mathrm{Cu}-\mathrm{Al}$ IMCs formed in a weld seam through a conventional welding method is the main reason for fractures of $\mathrm{Cu} / \mathrm{Al}$ joints, since the fractures are easily generated at the edge of coarse IMCs [9,10]. Fusion welding processes such as laser welding [11] have quality concerns including spatter, porosity, heat-affected zone or burn-through [12]. Moreover, these welding processes are easy to cause the excessive interaction of base materials and the formation of intermetallic phases with high hardness and brittleness [13]. However, solid state welding methods such as friction stir welding [14-16], ultrasonic welding [17], explosive welding [18] and electrical resistance welding [19] are able to suppress the growth of IMCs during the heating. Their restriction on the structure and size of the workpiece decreases the versatility and effectiveness of the processes.

Considering simplicity and non-restriction in shape and size as compared to solid state welding, brazing is an alternative method to achieve a $\mathrm{Cu} / \mathrm{Al}$ joint. Moreover, brazing allows a low process temperature with a thinner IMCs layer, which is beneficial to metallurgical bonding due to an interface reaction [20]. At present, the filler metals to braze $\mathrm{Cu} / \mathrm{Al}$ joints mainly consist of Al-Si alloy, $\mathrm{Sn}-\mathrm{Zn}$ 
alloy and $\mathrm{Zn}-\mathrm{Al}$ alloy. Xia et al. used an $\mathrm{Al}-\mathrm{Si}$ filler metal in vacuum brazing, finding that $\mathrm{Cu}_{3} \mathrm{Al}_{2}$ and $\mathrm{CuAl}_{2}$ formed in the region on the $\mathrm{Cu}$ side and in the brazing seam [21]. Due to the high liquidus temperature of Al-Si alloys, however, brazing processes usually require higher temperatures, which easily cause the overheating and even overburning of Al base metals. Moreover, the nucleation and growth of $\mathrm{Cu}-\mathrm{Al} \mathrm{IMC}$ are promoted at such a high process temperature. With regard to $\mathrm{Sn}-\mathrm{Zn}$ filler metal, the poor corrosion resistance of the brazed joint is a main problem. Huang et al. added Ag to $\mathrm{Sn}-\mathrm{Zn}$ alloys to increase potential, and thus improve their corrosion resistance, but the addition decreased the joint strength [22]. Considering the weakness of Al-Si and Sn-Zn alloys, Zn-Al filler metal becomes a hotspot due to its moderate melting point and excellent mechanical properties. The melting point of $\mathrm{Zn}-\mathrm{Al}$ alloy can be controlled in the range of $381-490^{\circ} \mathrm{C}$ with the change of the $\mathrm{Al}$ content, which is a suitable temperature to braze a $\mathrm{Cu} / \mathrm{Al}$ joint. Niu et al. obtained a $\mathrm{Cu} / \mathrm{Al}$ joint using $\mathrm{Zn}$-Al filler metal in an argon-shielded furnace, suggesting that $\mathrm{CuZn}, \mathrm{Al}_{4.2} \mathrm{Cu}_{3.2} \mathrm{Zn}_{0.7}, \mathrm{CuAl}_{2}, \mathrm{Cu}_{9} \mathrm{Al}_{4}$ and $\mathrm{CuAl}$ compounds could form at the $\mathrm{Cu}$ side interface depending on brazing parameters. They also claimed that when the thin $\mathrm{CuZn}$ and $\mathrm{Al}_{4.2} \mathrm{Cu}_{3.2} \mathrm{Zn}_{0.7}$ IMC layers formed, the joint possessed higher shear strength of up to 65-75 MPa [23]. Ji et al. added Ti and Ce into Zn-Al filler metal, finding that the addition of Ti and Ce decreased thickness of the IMC layer, and therefore resulted in a higher shear strength [24,25]. Additionally, $\mathrm{CuAl}_{2}, \mathrm{CuZn}$ and $\mathrm{Cu}_{9} \mathrm{Al}_{4}$ compounds were observed to form at the brazing seam/Cu substrate interface when $\mathrm{Zn}$-Al-xTi filler metal was used, which could further strengthen the joints. Xiao et al. achieved $\mathrm{Cu} / \mathrm{Al}$ joints using a $\mathrm{Zn}-3 \mathrm{Al}$ filler metal by an ultrasonic-assisted brazing method [26]. They indicated that when the brazing temperature increased to $440{ }^{\circ} \mathrm{C}$, a thin $\mathrm{Al}_{4.2} \mathrm{Cu}_{3.2} \mathrm{Zn}_{0.7} \mathrm{IMC}$ layer formed at the brazing seam/Cu interface, which helped to increase the shear strength of the joint to $78.93 \mathrm{MPa}$.

In a $\mathrm{Cu} / \mathrm{Al}$ brazing joint, reactions at brazing seam/Cu interfaces, in brazing seams and at $\mathrm{Al} / \mathrm{brazing}$ seam interfaces all have a great influence on the performances of the $\mathrm{Cu} / \mathrm{Al}$ joints. However, existing research mostly focuses on the reactions and microstructures at the brazing seam/Cu interfaces [27]; influences of the reactions in brazing seams and at $\mathrm{Al} / \mathrm{brazing}$ seam interfaces on joint properties are barely studied. Moreover, most researchers used a pure $\mathrm{Al}$ or $1 \times \times \times$ series $\mathrm{Al}$ alloy as a base metal [28-30], while $3003 \mathrm{Al}$ alloy is rarely researched. Compared with pure $\mathrm{Al}$ or $1 \times \times \times$ series $\mathrm{Al}$ alloy, $3003 \mathrm{Al}$ alloy presents more excellent mechanical properties due to the addition of $\mathrm{Mn}$. In this study, $3003 \mathrm{Al}$ alloy and $\mathrm{T} 2 \mathrm{Cu}$ were used as the base metals to obtain a $\mathrm{Cu} / \mathrm{Al}$ joint. $\mathrm{Zn}$-xAl alloys, with the $\mathrm{Al}$ content ranging from $2 \mathrm{wt} . \%$ to $25 \mathrm{wt} . \%$, were used as filler metals to investigate the influences of interfacial reactions on joint strength. $1035 \mathrm{Al} / \mathrm{Cu}$ joints were also obtained to be compared with $3003 \mathrm{Al} / \mathrm{Cu}$ joints. This paper investigated the effect of $\mathrm{Al}$ content in the $\mathrm{Zn}-\mathrm{Al}$ filler metal on the interfacial microstructure of $3003 \mathrm{Al} / \mathrm{T} 2 \mathrm{Cu}$ and $1035 \mathrm{Al} / \mathrm{T} 2 \mathrm{Cu}$ brazing joints, as well as the bulk IMC ratio in the brazing seam. The evolution mechanisms of the joint shear strength and fracture behavior were discussed by analyzing the changes of the IMC layer thickness and the bulk IMC ratio. Finally, the optimum compositions of $\mathrm{Zn}-\mathrm{Al}$ filler metal for the above two $\mathrm{Cu} / \mathrm{Al}$ joints were obtained. The results provide guidance for choosing appropriate filler metal and achieving highly reliable $\mathrm{Cu} / \mathrm{Al}$ dissimilar joints for the refrigeration and electric power industries.

\section{Materials and Methods}

The commercial flux CsF-AlF 3 (Zhejiang Xinrui Welding Material Co., Ltd., Shaoxing, China) was applied to remove the oxide film of a base metal and improve its wettability. The melting point of the flux CsF-AlF 3 is about $475^{\circ} \mathrm{C}$. The chemical composition of $\mathrm{Zn}-\mathrm{xAl}$ filler metals is shown in Table 1. The filler metals were produced by Zhejiang Xinrui Welding Material Co., Ltd. (Shaoxing, China). The melting point of $\mathrm{Zn}$-Al alloy can be controlled in the range of $381-490^{\circ} \mathrm{C}$ with the change of $\mathrm{Al}$ content

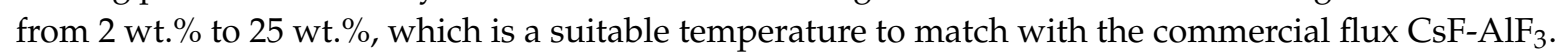
Moreover, it is a proper temperature to braze copper/aluminum $(\mathrm{Cu} / \mathrm{Al})$ joints without overheating. Plates $(60 \mathrm{~mm} \times 25 \mathrm{~mm} \times 3 \mathrm{~mm}$ ) of $1035 \mathrm{Al}$ alloy, $3003 \mathrm{Al}$ alloy and $\mathrm{T} 2 \mathrm{Cu}$ (hereinafter referred to as $1035 \mathrm{Al}, 3003 \mathrm{Al}$ and $\mathrm{Cu}$ ) were used as base metals. The composition of copper plates and aluminum 
plates are shown in Table 2. Before brazing, contaminants layers (oxides, grease and dust particles) adhering to the surfaces of base metals were removed. The $1035 \mathrm{Al}$ plates and $3003 \mathrm{Al}$ plates were cleaned with $60^{\circ} \mathrm{C} 5 \mathrm{wt} . \% \mathrm{NaOH}$ solution for $10-15 \mathrm{~s}$, and then rinsed with water. The $\mathrm{Cu}$ plates were soaked in $15 \mathrm{wt} . \% \mathrm{H}_{2} \mathrm{SO}_{4}$ for $15 \mathrm{~min}$, and then rinsed with water. After rinsing, all plates were dried with warm air [31].

Table 1. Composition of filler metals (wt.\%).

\begin{tabular}{ccccccc}
\hline Element & $\mathbf{1}$ & $\mathbf{2}$ & $\mathbf{3}$ & $\mathbf{4}$ & $\mathbf{5}$ & $\mathbf{6}$ \\
\hline $\mathrm{Al}$ & 2 & 5 & 12 & 15 & 20 & 25 \\
$\mathrm{Zn}$ & 98 & 95 & 88 & 85 & 80 & 75 \\
\hline
\end{tabular}

Table 2. Composition of copper plates and aluminum plates.

\begin{tabular}{|c|c|c|c|c|c|c|c|c|c|c|c|c|c|c|}
\hline \multirow{2}{*}{ Material } & \multicolumn{14}{|c|}{ Composition (wt.\%) } \\
\hline & $\mathrm{Al}$ & $\mathrm{Zn}$ & $\mathrm{Cu}$ & $\mathrm{Fe}$ & $\mathrm{Sb}$ & V & Si & $\mathrm{Mg}$ & Mn & As & $\mathbf{B i}$ & $\mathbf{P b}$ & $\mathrm{Ti}$ & $S$ \\
\hline 1035 & Bal. & 0.1 & 0.1 & 0.6 & - & 0.05 & 0.35 & 0.05 & 0.05 & - & - & - & 0.03 & - \\
\hline 3003 & Bal. & 0.1 & $0.05 \sim 0.2$ & 0.7 & - & - & 0.6 & & $1.0 \sim 1.5$ & - & - & - & - & - \\
\hline $\mathrm{T} 2 \mathrm{Cu}$ & - & - & Bal. & 0.005 & 0.002 & - & - & - & - & 0.002 & 0.001 & 0.005 & - & 0.005 \\
\hline
\end{tabular}

Flame brazing was utilized as a brazing method to obtain lap joints with a lap width of $3 \mathrm{~mm}$. A schematic diagram of the lap $\mathrm{Cu} / \mathrm{Al}$ brazed joint is shown in Figure 1. A fire-suction welding torch (H01-12, Qingdao Yinte Fardware Tools Co., Ltd., Qingdao, China) was used to join $\mathrm{Cu}$ and $\mathrm{Al}$ specimens. Shear strength was chosen to estimate the joint strength, and the average shear strength was determined by six specimens. A universal tensile testing machine (SANS-CMT5105, Changchun Test Machine Research Institute, Changchun, China) was used to conduct the shear test. The shear force was divided by the shearing area of the brazed joint to calculate the shear strength. The shear force equals the max load applied in the fracture course of the brazed joint. The lap area of the brazed joint before the shear test was measured as the shearing area. Microstructures of $1035 \mathrm{Al} / \mathrm{Cu}$ brazed joints were characterized by an optical microscope (XJP-300, Shanghai Optical Instrument Five Factory, Shanghai, China), and joint fractures were analyzed by a scanning electron microscope (SEM, S-3000, HITACHI corporation, Tokyo, Japan) with energy dispersive spectroscopy (EDS). Microstructures of $3003 \mathrm{Al} / \mathrm{Cu}$ brazed joints were characterized by an optical microscope (Axio Imager AIM, Carl Zeiss, Oberkochen, Germany), and joint fractures were analyzed by a FEG electron microscope (Quanta 250, FEI Corporation, Hillsboro, USA) with EDS. The area of the IMC layer (dark area) at the Cu side was measured digitally by Image Pro-Plus software, as shown in Figure 2. The average thickness of the IMC layer $(d)$ was then calculated with the following Equation (1)

$$
d=A / l
$$

where $(A)$ is the IMC layer area and $(l)$ is the length of the IMC layer. Meanwhile, the area of bulk IMC was measured with Image Pro-Plus, as shown in Figure 3. The IMC ratio in the brazing seam in which the IMC layer is not included was calculated by the following Equation (2)

$$
N=A 3 /(A 1-A 2)
$$

where $(A 3)$ is the bulk IMC area, $(A 1)$ is the total brazing seam area and $(A 2)$ is the IMC layer area at the $\mathrm{Cu}$ side. 


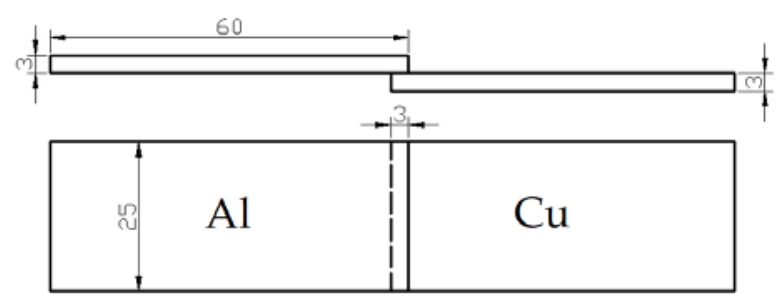

Figure 1. The schematic diagram of the lap $\mathrm{Cu} / \mathrm{Al}$ brazed joint (unit: $\mathrm{mm}$ ).

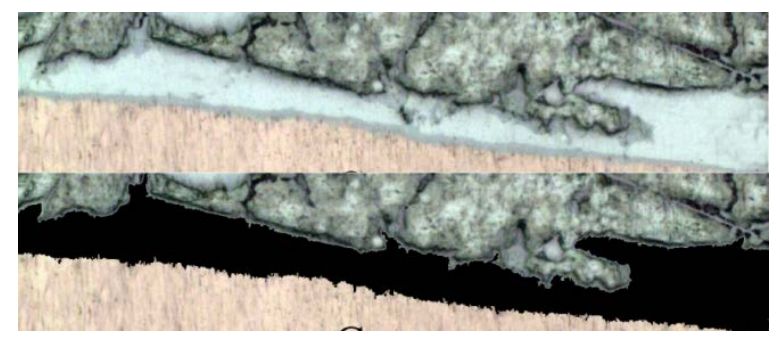

Figure 2. The schematic diagram for the calculation of the IMC layer area.

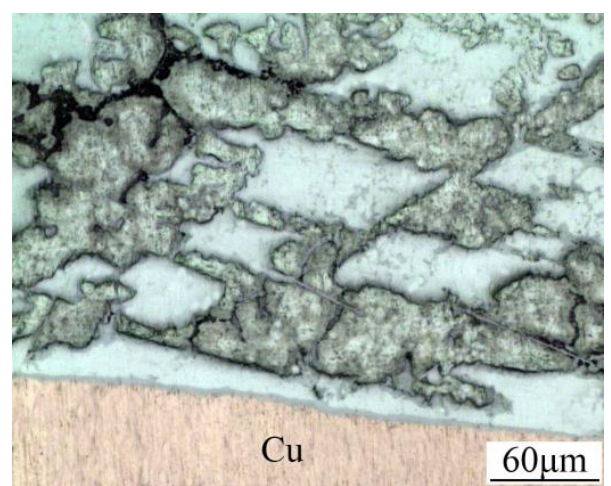

(a)

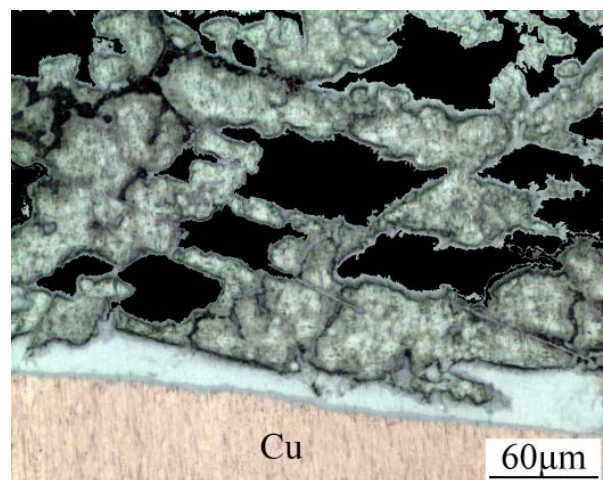

(b)

Figure 3. The schematic diagram for the calculation of bulk IMC area: (a) the original image; and (b) the image processed by Image Pro-Plus software.

\section{Result and Discussion}

\subsection{Joint Mechanical Property}

Macro fracture surfaces of 3003 aluminum/copper $(\mathrm{Al} / \mathrm{Cu})$ and $1035 \mathrm{Al} / \mathrm{Cu}$ joints are shown in Figure 4; Figure 5. Both $3003 \mathrm{Al} / \mathrm{Cu}$ and $1035 \mathrm{Al} / \mathrm{Cu}$ joints were fractured in brazing seams, and had similar morphology. After shearing, the brazing seam alloys mostly attached to Al sides, and a thin IMC layer could be observed on the $\mathrm{Cu}$ sides, which implied that the fracture occurred at a brazing seam/IMC layer interface at the $\mathrm{Cu}$ sides.

Figure 6 shows the average shear strength of $3003 \mathrm{Al} / \mathrm{Cu}$ and $1035 \mathrm{Al} / \mathrm{Cu}$ joints brazed by $\mathrm{Zn}-\mathrm{xAl}$ filler metals. With the increase of $\mathrm{Al}$ content in the filler metals, the shear strength of both $3003 \mathrm{Al} / \mathrm{Cu}$ and $1035 \mathrm{Al} / \mathrm{Cu}$ joints increased first, then decreased. The $3003 \mathrm{Al} / \mathrm{Cu}$ joints brazed by $\mathrm{Zn}-12 \mathrm{Al}$ achieved the highest average shear strength of $94.37 \mathrm{MPa}$, while the $1035 \mathrm{Al} / \mathrm{Cu}$ joints brazed by $\mathrm{Zn}-15 \mathrm{Al}$ achieved the highest average shear strength of $44.04 \mathrm{MPa}$ among the same kind of base metal. Obviously, shear strengths of $3003 \mathrm{Al} / \mathrm{Cu}$ joints were greatly higher than that of $1035 \mathrm{Al} / \mathrm{Cu}$ joints. 

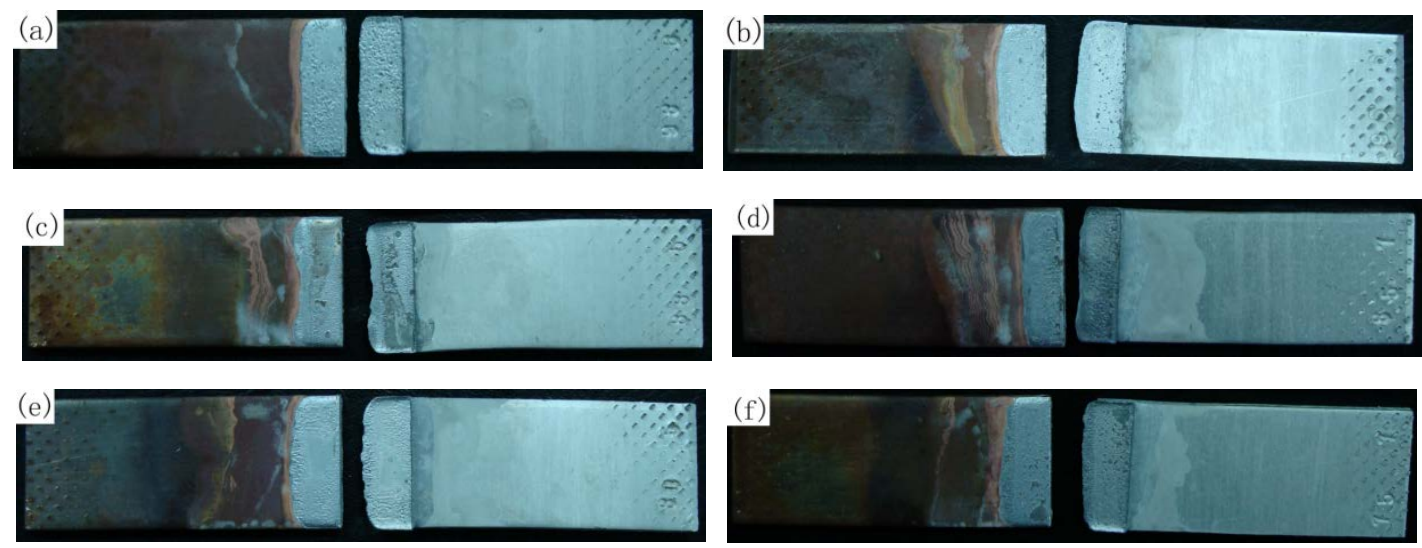

Figure 4. Macro fracture surfaces of $3003 \mathrm{Al} / \mathrm{Cu}$ joint brazed by (a) $\mathrm{Zn}-2 \mathrm{Al}$; (b) Zn-5Al; (c) Zn-12Al; (d) Zn-15Al; (e) Zn-20Al; and (f) Zn-25Al.
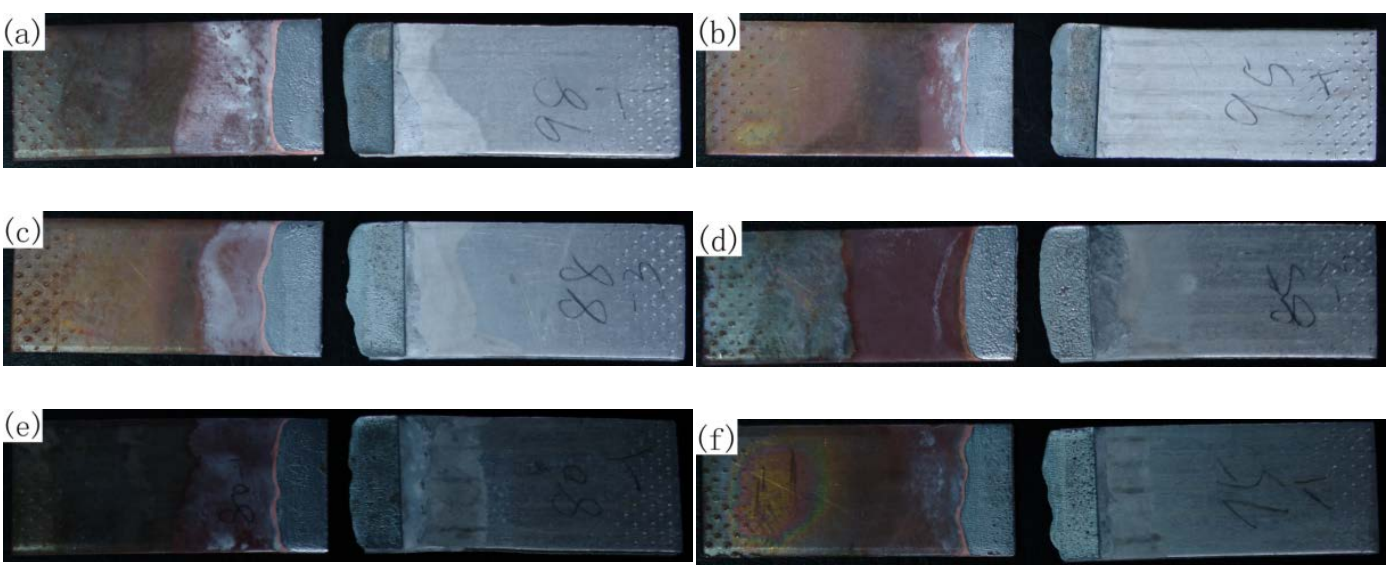

Figure 5. Macro fracture surfaces of $1035 \mathrm{Al} / \mathrm{Cu}$ joint brazed by (a) $\mathrm{Zn}-2 \mathrm{Al}$; (b) Zn-5Al; (c) Zn-12Al; (d) Zn-15Al; (e) Zn-20Al; and (f) Zn-25Al.

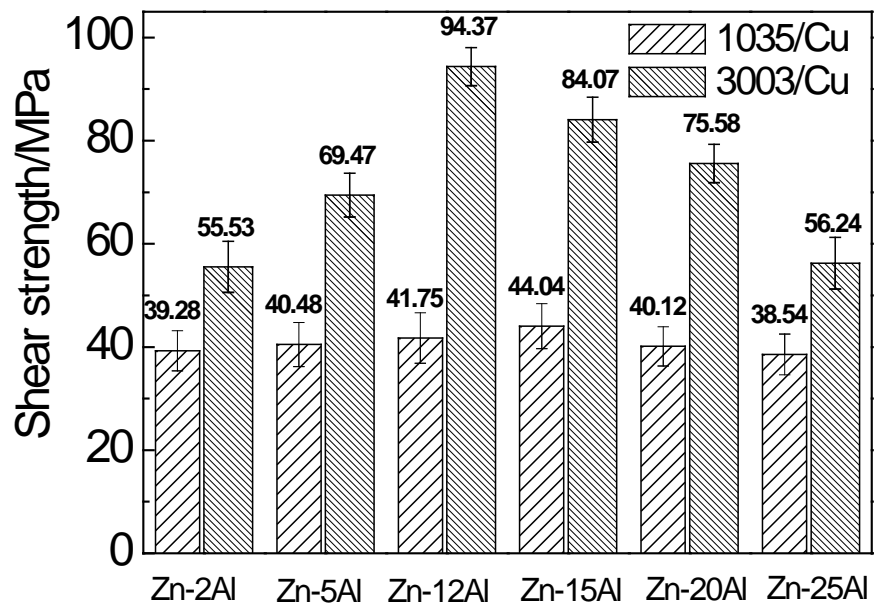

Figure 6. Shear strength of $3003 \mathrm{Al} / \mathrm{Cu}$ and $1035 \mathrm{Al} / \mathrm{Cu}$ joints brazed by the $\mathrm{Zn}-\mathrm{xAl}$ filler metals.

\subsection{Microstructures of $3003 \mathrm{Al} / \mathrm{Cu}$ Brazed Joints}

Figure 7 shows the microstructures of $\mathrm{Al} / \mathrm{brazing}$ seam interfaces of $3003 \mathrm{Al} / \mathrm{Cu}$ joints. During solidification, heterogeneous nucleation of the brazing seam alloys occurred on surfaces of the $\mathrm{Al}$ plates, and then formed an Al-based solid solution that grew towards the center of the brazing seam, resulting in a sound joint. 

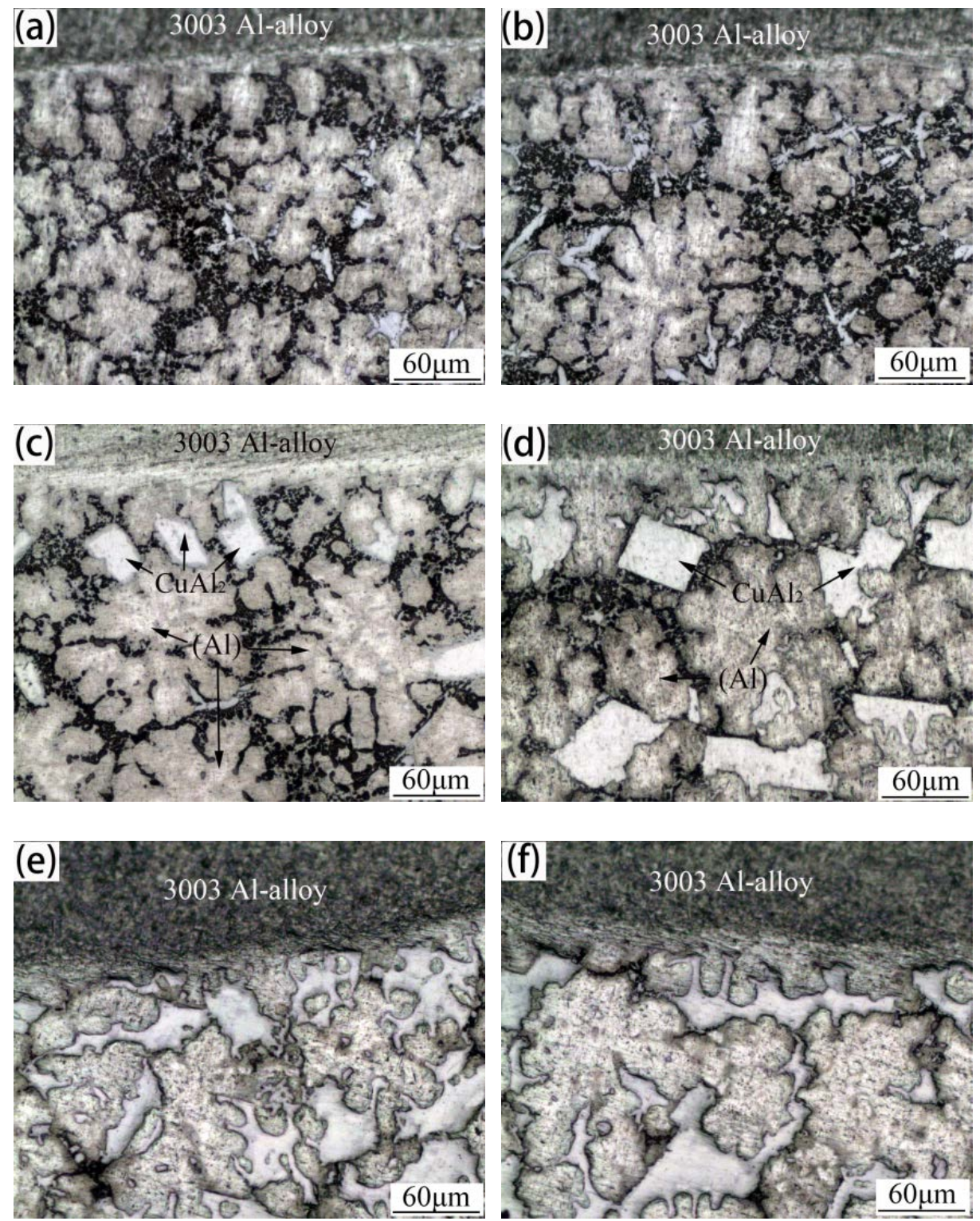

Figure 7. Microstructures of $\mathrm{Al} /$ brazing seam interfaces of $3003 \mathrm{Al} / \mathrm{Cu}$ joints brazed by (a) $\mathrm{Zn}-2 \mathrm{Al}$; (b) Zn-5Al; (c) Zn-12Al; (d) Zn-15Al; (e) Zn-20Al; and (f) Zn-25Al.

The microstructures of a brazing seam/Cu interface of $3003 \mathrm{Al} / \mathrm{Cu}$ joints are shown in Figures 8 and 9. According to the Al-Cu phase diagram and the energy dispersive spectroscopy (EDS) result (Table 3), the phase transition during the brazing process is illustrated as follows. CuAl layers formed at brazing seam/Cu interface, while bulk $\mathrm{CuAl}_{2}$ and $\mathrm{CuAl}$ formed and dispersed in the brazing seam alloys. Meanwhile, the brazing seam alloys mainly composed of Al-based and Zn-based solid solutions.

Table 3. EDS results of chemical compositions (at.\%) of points marked in Figure 9.

\begin{tabular}{ccccc}
\hline Point & Al & Cu & Zn & Mn \\
\hline A & 63.16 & 36.84 & - & - \\
B & 57.08 & 42.92 & - & - \\
C & 52.97 & 47.03 & - & - \\
D & 81.29 & 6.52 & 11.22 & 0.97 \\
\hline
\end{tabular}



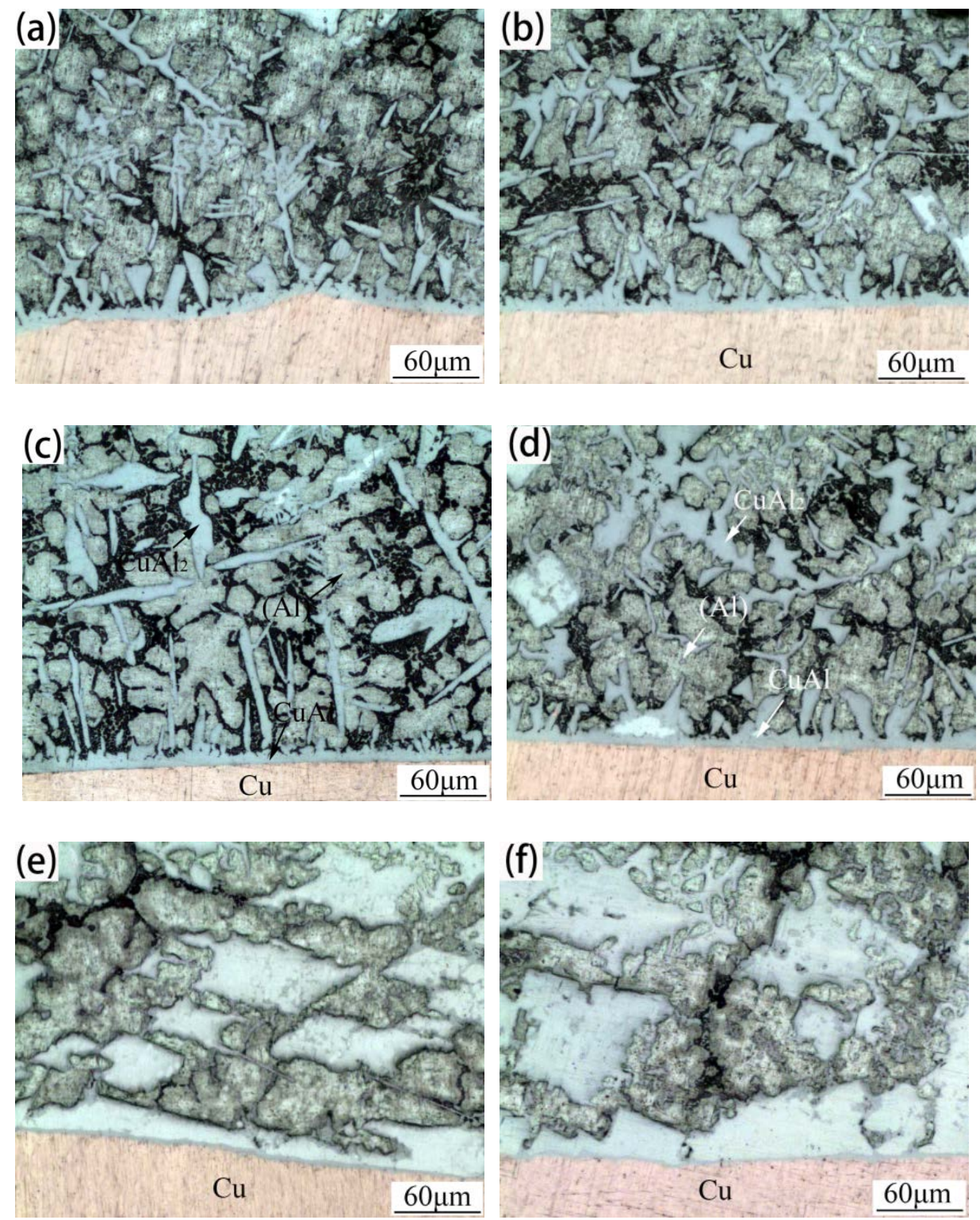

Figure 8. Microstructures of $\mathrm{Cu}$ /brazing seam interfaces of $3003 \mathrm{Al} / \mathrm{Cu}$ joints brazed by (a) $\mathrm{Zn}-2 \mathrm{Al}$; (b) Zn-5Al; (c) Zn-12Al; (d) Zn-15Al; (e) Zn-20Al; and (f) Zn-25Al.

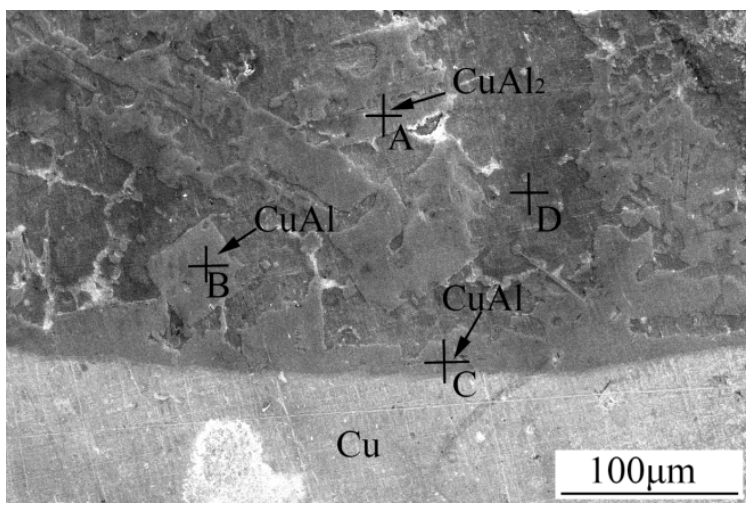

Figure 9. SEM image of $\mathrm{Cu} /$ brazing seam interfaces of $3003 \mathrm{Al} / \mathrm{Cu}$ joints brazed by $\mathrm{Zn}-25 \mathrm{Al}$. 
By comparing Figures 7 and 8, it can be found that the amount of bulk $\mathrm{Cu}-\mathrm{Al}$ IMCs at the $\mathrm{Cu}$ side was more than that of the $\mathrm{Al}$ side. Because $\mathrm{Cu}$ atom concentration was higher at the $\mathrm{Cu}$ side, it was favorable for $\mathrm{Cu}-\mathrm{Al} \mathrm{IMC}$ to form. Meanwhile, the microstructure was more complicated at the $\mathrm{Cu}$ side, and a layer of $\mathrm{CuAl}$ IMC could be observed at the interface of the brazing seam/Cu. The hardness of the IMC layer was significantly higher than that of the brazing seam. Therefore, compared with that of the $\mathrm{Al}$ side, the interface at the $\mathrm{Cu}$ side became a weak area.

Figure 10 shows the schematic diagram of the microstructure of the $\mathrm{Cu} / \mathrm{Al}$ joint. The $\mathrm{Al}-\mathrm{Cu}$ and $\mathrm{Zn}-\mathrm{Cu}$ phase diagrams suggest that $\mathrm{Al}$ is able to form IMC with both $\mathrm{Cu}$ and $\mathrm{Zn}$, but $\mathrm{Al}$ preferentially reacts with $\mathrm{Cu}$ to form IMC due to a stronger chemical affinity between $\mathrm{Al}$ and $\mathrm{Cu}$, which is estimated from the electronegativity difference among the three (Al: 1.61, $\mathrm{Zn:} 1.65$ and $\mathrm{Cu}: 1.9)$ [32]. Additionally, $\mathrm{Cu}$ atoms that concentrated in the molten brazing seam alloys on $\mathrm{Cu}$ sides promoted the formation of $\mathrm{CuAl}$. Therefore, $\mathrm{CuAl}$ was the dominating phase both at the brazing seam/Cu interface and in brazing seams that were near $\mathrm{Cu}$ sides, while the formation of bulk $\mathrm{CuAl}_{2}$ was promoted in the other regions further away from $\mathrm{Cu}$ base metal, hence the higher $\mathrm{Al}$ atom concentration. However, the hardness of the brittle $\mathrm{CuAl}$ layer is much higher than that of brazing seam alloys, which caused a stiffness mismatch. The hardness $\mathrm{HV}(10 \mathrm{~g})$ of $\mathrm{CuAl}, \mathrm{CuAl}_{2}, \mathrm{Cu}$ and $\mathrm{Al}$ are 905, 630, 75 and 36, respectively, which are taken from [30]. Compared with other phases, the hardness of $\mathrm{CuAl}$ is extremely high. Therefore, under an external stress load, cracks are prone to occur at the brazing seam/CuAl IMC layer interface due to stress concentration, and propagate along the edge of the IMC layer, as shown in Figure 10.

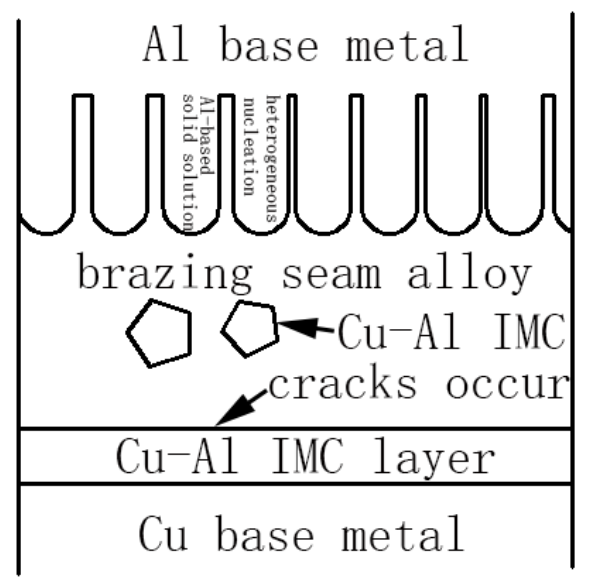

Figure 10. Schematic diagram of microstructure in the $\mathrm{Cu} / \mathrm{Al}$ brazed joint.

The formation of $\mathrm{Cu}-\mathrm{Al} \mathrm{IMC}$ at the interface and inside the brazing seam alloys is driven by the diffusion of $\mathrm{Cu}$ and $\mathrm{Al}$ atoms. During the solidification of brazing seam alloys, the diffusion exists inside $\mathrm{Cu}-\mathrm{Al} \mathrm{IMC}$ and brazing seam alloys, as well as at $\mathrm{Cu}-\mathrm{Al} \mathrm{IMC} /$ brazing seam interface and brazing seam alloy/base metal interfaces. Figure 11 shows the IMC layer thickness and the bulk IMC ratio in Figure 8. For the joint brazed by $\mathrm{Zn}-2 \mathrm{Al}$, the IMC layer thickness and the bulk IMC ratio are $11.01 \mu \mathrm{m}$ and $9.91 \%$, respectively. The microstructure was mainly composed of an Al-based and Zn-based solid solution, as lower $\mathrm{Al}$ atom concentration led to slower diffusion, hence less $\mathrm{Cu}-\mathrm{Al} \mathrm{IMC}$. However, the $\mathrm{Al}$-based and $\mathrm{Zn}$-based solid solutions are much softer than the brittle $\mathrm{CuAl}$ layer at the $\mathrm{Cu}$ side, which could induce stress concentration and cracks under an external stress load, as mentioned-therefore, the shear strength was lower. When $\mathrm{Al}$ content is less and equal to $12 \mathrm{wt} \%$, the IMC layer thickness becomes thinner and the bulk IMC ratio gets higher with the increase of the Al content, as shown in Figure 11. 


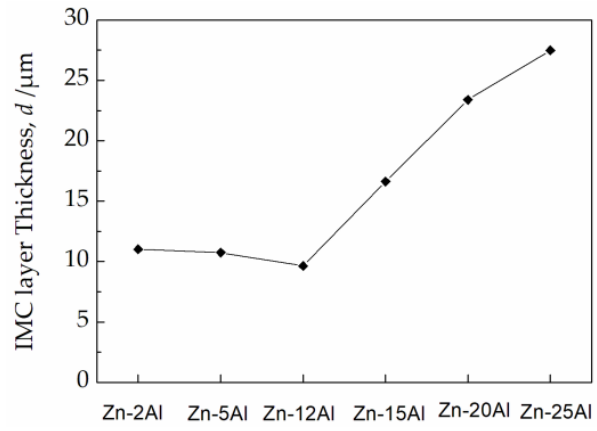

(a)

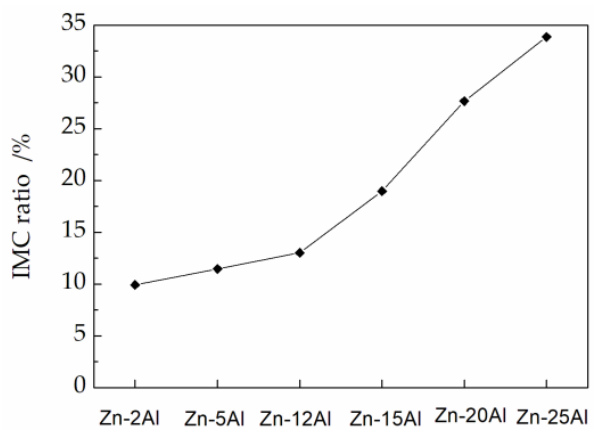

(b)

Figure 11. Changes of (a) IMC layer thickness and (b) bulk IMC ratio in Figure 8.

When the $\mathrm{Al}$ content of $\mathrm{Zn}-\mathrm{xAl}$ filler metals reached $12 \mathrm{wt} . \%$, the ratio of bulk $\mathrm{Cu}-\mathrm{Al} \mathrm{IMC}$ increased to $13.01 \%$. This is because $\mathrm{Cu}$ diffusion from base metals to brazing seam alloys has been promoted with increasing $\mathrm{Al}$ atom concentration, driven by the strong chemical affinity between $\mathrm{Al}$ and $\mathrm{Cu}$. The hardness of the bulk $\mathrm{Cu}-\mathrm{Al}$ IMC is much larger than that of the Al-based and the $\mathrm{Zn}$-based solid solution, which can work as dispersion strengthening phases to increase the joint strength. On the other hand, the $\mathrm{CuAl}$ layer formed at the $\mathrm{Cu}$ side gets thinner to $9.64 \mu \mathrm{m}$, therefore the effect of the mismatch of stiffness and stress concentration should be lesser. Thus, the joints brazed by Zn-12Al possessed the highest shear strength. When the $\mathrm{Al}$ content exceeded $12 \mathrm{wt} . \%$, the formation of the $\mathrm{Cu}-\mathrm{Al}$ IMC was further promoted, hence the coarse bulk $\mathrm{Cu}-\mathrm{Al}$ IMC in the brazing seam. Meanwhile, the IMC layer thickness became bigger and the bulk IMC ratio increased significantly. Coarse brittle $\mathrm{Cu}-\mathrm{Al}$ IMCs readily cause stress concentration and crack initiation, which decreases the joint strength.

During solidification, $\mathrm{Al}$ and $\mathrm{Mn}$ atoms in $3003 \mathrm{Al}$ base metals diffused into a brazing seam. According to the Al-Mn and Zn-Mn phase diagrams, a small amount of Mn dissolves into $\mathrm{Al}$ and $\mathrm{Zn}$, forming a solid solution. The EDS result (Table 3, point D) confirms the existence of $\mathrm{Mn}$ in the brazing seam alloy. Due to the similar atomic radii of $\mathrm{Al}$ (118 pm), Zn (125 pm) and Mn (117 pm) [33], $\mathrm{Mn}$ atoms in 3003Al readily formed a substitutional solid solution with both $\mathrm{Al}$ and $\mathrm{Zn}$. Because of the dissolution of $\mathrm{Mn}$, brazing seam alloys of $3003 \mathrm{Al} / \mathrm{Cu}$ joints possess larger lattice distortion and stronger solution strengthening, compared with that of $1035 \mathrm{Al} / \mathrm{Cu}$ joints. Therefore, $3003 \mathrm{Al} / \mathrm{Cu}$ joints with an Mn addition have a higher joint strength than $1035 \mathrm{Al} / \mathrm{Cu}$ joints.

\subsection{Microstructures of $1035 \mathrm{Al} / \mathrm{Cu}$ Brazed Joints}

Figure 12 shows the microstructures of $\mathrm{Al} / \mathrm{brazing}$ seam interfaces of $1035 \mathrm{Al} / \mathrm{Cu}$ joints. Similar to $3003 \mathrm{Al} / \mathrm{Cu}$ joints, the heterogeneous nucleation of the brazing seam alloy occurred on surfaces of the Al plates, resulting in sound joints, and the fractures mainly occurred at the brazing seam/IMC layer interface at the $\mathrm{Cu}$ sides.
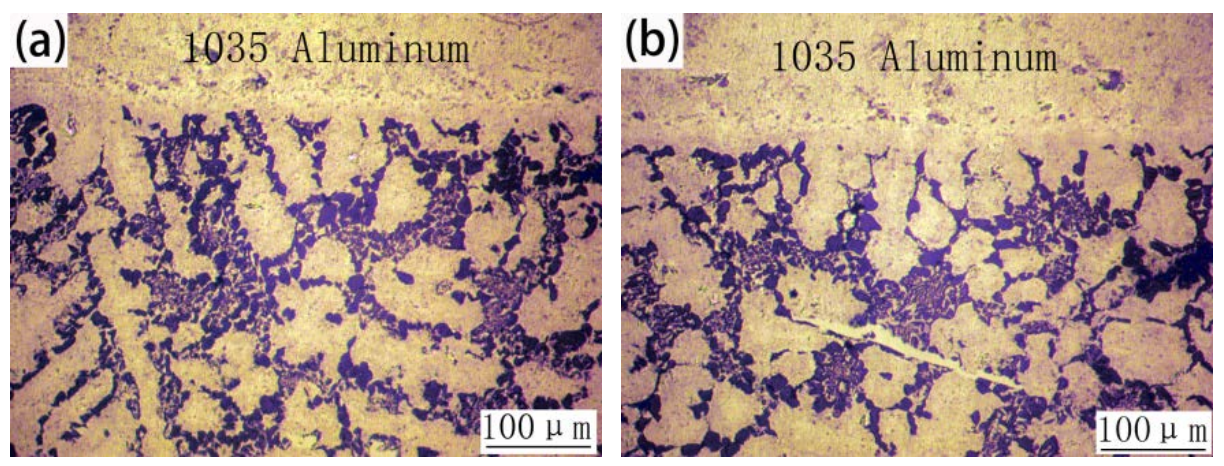

Figure 12. Cont. 

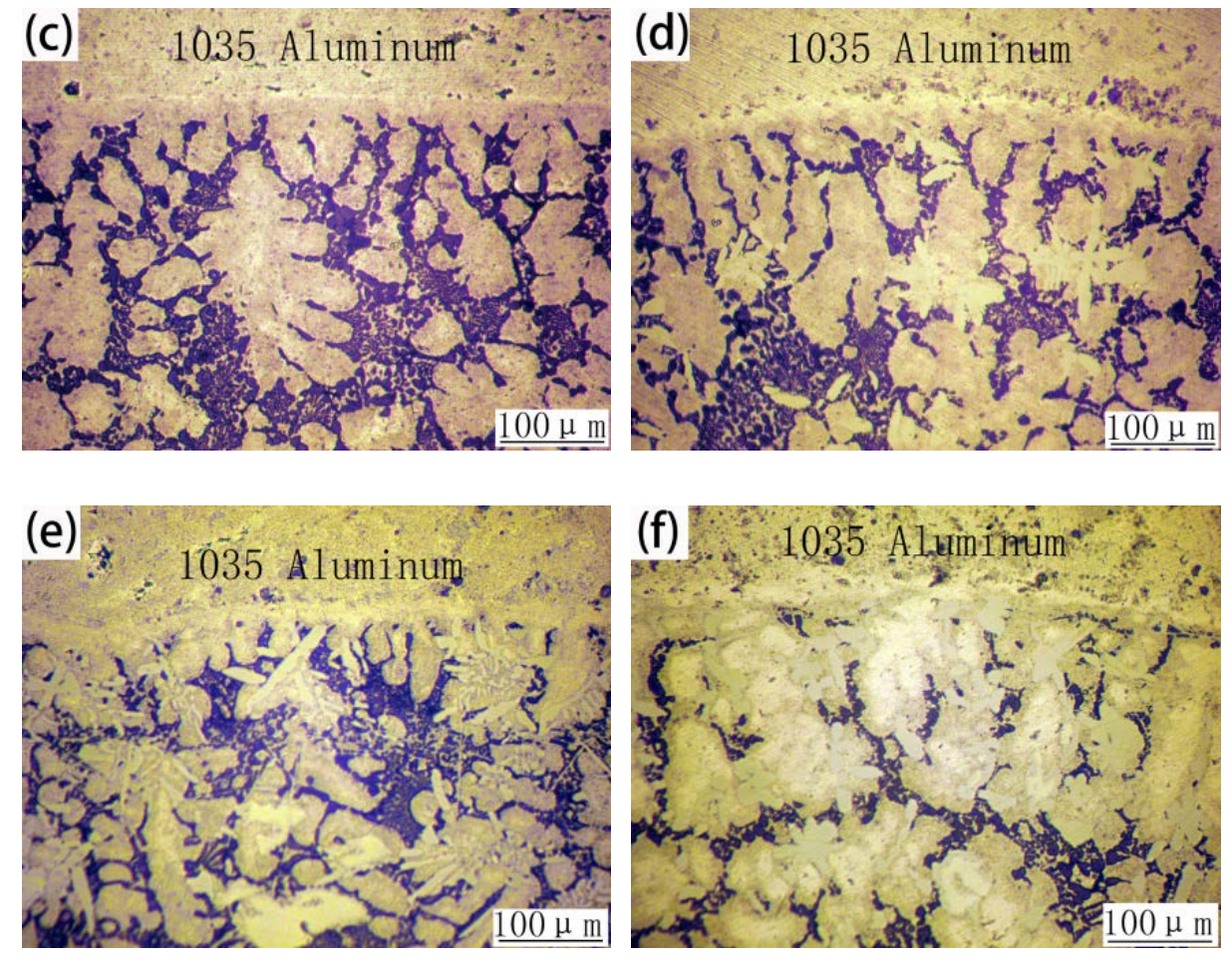

Figure 12. Microstructures of $\mathrm{Al} /$ brazing seam interfaces of $1035 \mathrm{Al} / \mathrm{Cu}$ joints brazed by (a) $\mathrm{Zn}-2 \mathrm{Al}$; (b) Zn-5Al; (c) Zn-12Al; (d) Zn-15Al; (e) Zn-20Al; and (f) Zn-25Al.

The microstructures of brazing seam/Cu interfaces of $1035 \mathrm{Al} / \mathrm{Cu}$ joints are shown in Figures 13 and 14. A continuous IMC layer, which is suggested to be $\mathrm{Al}_{4.2} \mathrm{Cu}_{3.2} \mathrm{Zn}_{0.7}$ by EDS results shown in Table 4, formed at the brazing seam/Cu interface. However, the brazing seam alloy was mainly composed of an Al-based and $\mathrm{Zn}$-based solid solution, while bulk $\mathrm{CuAl}_{2}$ was formed in the brazing seams. The hardness of $\mathrm{Al}_{4.2} \mathrm{Cu}_{3.2} \mathrm{Zn}_{0.7}$ and $\mathrm{Cu}$ are $11.40 \mathrm{GPa}$ and $2.02 \mathrm{GPa}$, respectively [26]. Consequently, the hardness of $\mathrm{Al}_{4.2} \mathrm{Cu}_{3.2} \mathrm{Zn}_{0.7}$ is extremely high in comparison with the $\mathrm{Zn}$-based or Al-based solid solution. Therefore, under an external stress load, cracks are prone to occur at the brazing seam/ $/ \mathrm{Al}_{4.2} \mathrm{Cu}_{3.2} \mathrm{Zn}_{0.7}$ IMC layer interface.

Similar to $3003 \mathrm{Al} / \mathrm{Cu}$ joints, the interface reaction of brazing seam/Cu interfaces in $1035 \mathrm{Al} / \mathrm{Cu}$ joints was much more complex due to the higher $\mathrm{Cu}$ concentration at $\mathrm{Cu}$ sides than that of $\mathrm{Al}$ sides. After brazing, a continuous IMC layer and more bulk $\mathrm{Cu}$-Al IMCs formed at this interface, and the great gap of stiffness between the IMC layer and brazing seam alloy could easily induce stress concentration and crack initiation. Therefore, the joint strength was mainly decided by the microstructure and performance of the brazing seam/Cu interface. Figure 5 also showed that the fracture location was at brazing seam/Cu interface, indicating that this interface was a weak area.

$\mathrm{Cu}-\mathrm{Al} \mathrm{IMCs}$ at brazing seam/Cu interface and in brazing seam alloys are essentially due to the diffusion and combination of $\mathrm{Cu}$ and $\mathrm{Al}$ atoms. Figure 15 shows the IMC layer thickness and the bulk IMC ratio of the interfacial structures shown in Figure 13. For the joint brazed by $\mathrm{Zn}-2 \mathrm{Al}$, the IMC layer thickness and the bulk IMC ratio are $14.33 \mu \mathrm{m}$ and just $0 \%$. The bulk $\mathrm{CuAl}_{2}$ barely formed, as a lower $\mathrm{Al}$ atom concentration led to slower diffusion. The ratio of bulk $\mathrm{CuAl}_{2}$ increases with the increase of $\mathrm{Al}$ content in the filler metals. Fine $\mathrm{CuAl}_{2}$ bulks dispersed in brazing seams alloys, which thus increased their stiffness; the effect of the mismatch of stiffness between the brazing seam alloy and the IMC layer at the $\mathrm{Cu}$ side was therefore reduced. Hence, the joint strength increased with increasing $\mathrm{Al}$ content. When the $\mathrm{Al}$ content reached $15 \mathrm{wt} . \%$, the bulk IMC ratio increased to $5.82 \%$. On the other hand, the IMC layer becomes thinner with a thickness of $11.43 \mu \mathrm{m}$, showing that stress concentration was suppressed, and it was difficult for the crack to initiate at the at brazing seam/Cu interface, resulting in the highest joint strength. 

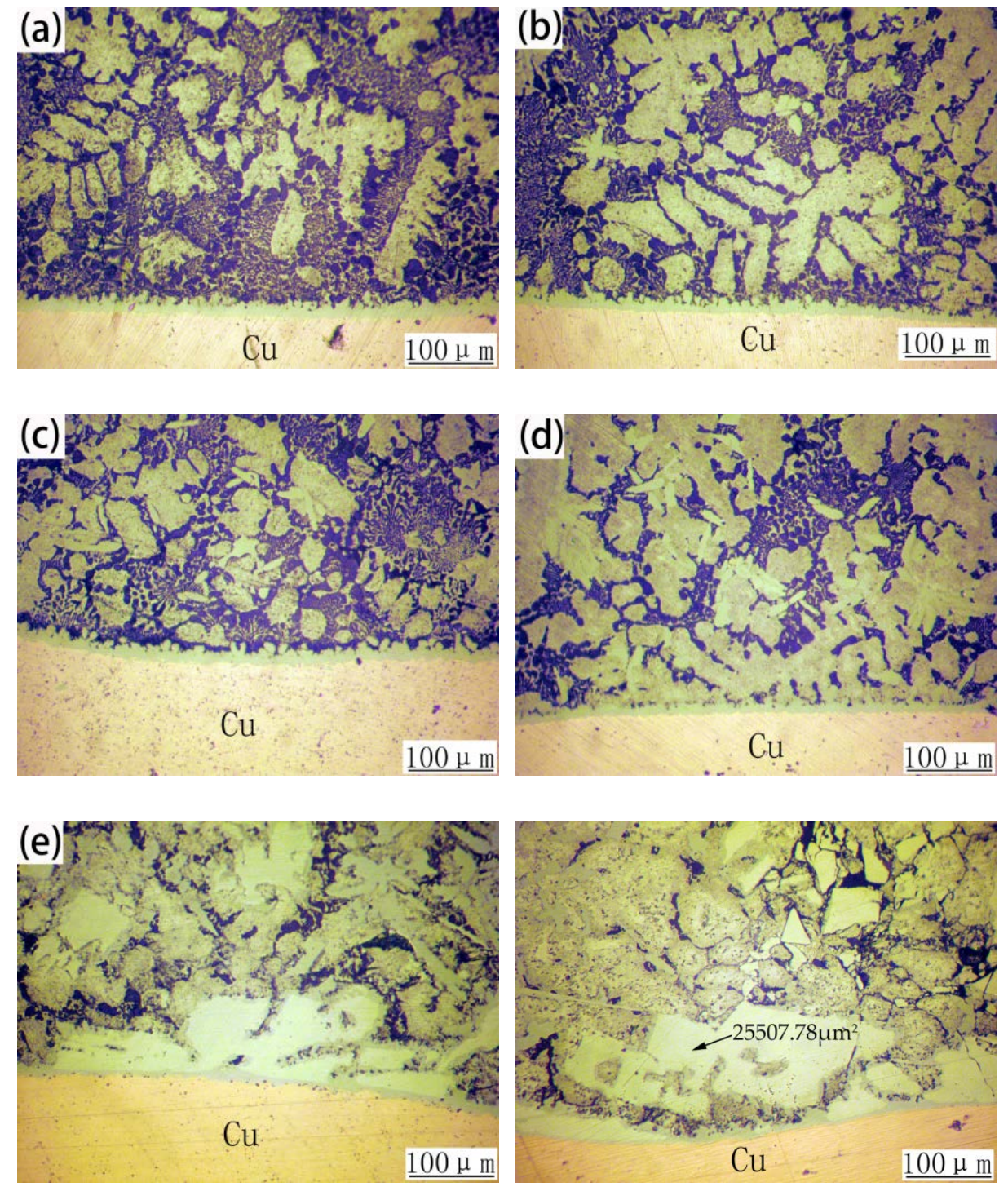

Figure 13. Microstructures of brazing seam/ $\mathrm{Cu}$ interfaces of $1035 \mathrm{Al} / \mathrm{Cu}$ joints brazed by (a) $\mathrm{Zn}-2 \mathrm{Al}$; (b) Zn-5Al; (c) Zn-12Al; (d) Zn-15Al; (e) Zn-20Al; and (f) Zn-25Al.

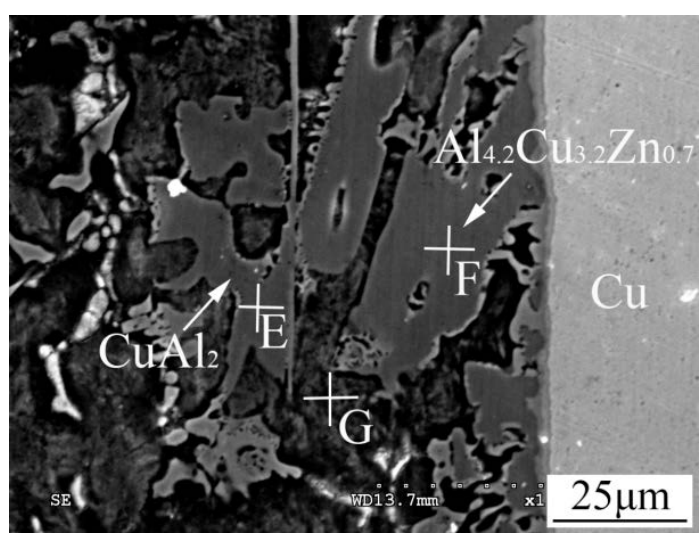

Figure 14. SEM image of brazing seam/Cu interfaces of $1035 \mathrm{Al} / \mathrm{Cu}$ joint brazed by $\mathrm{Zn}-15 \mathrm{Al}$. 
Table 4. EDS results of chemical compositions (at. \%) of points marked in Figure 14.

\begin{tabular}{cccc}
\hline Point & Al & Cu & Zn \\
\hline E & 67.42 & 30.27 & 2.31 \\
F & 56.26 & 35.98 & 7.76 \\
G & 75.91 & 5.34 & 18.75 \\
\hline
\end{tabular}

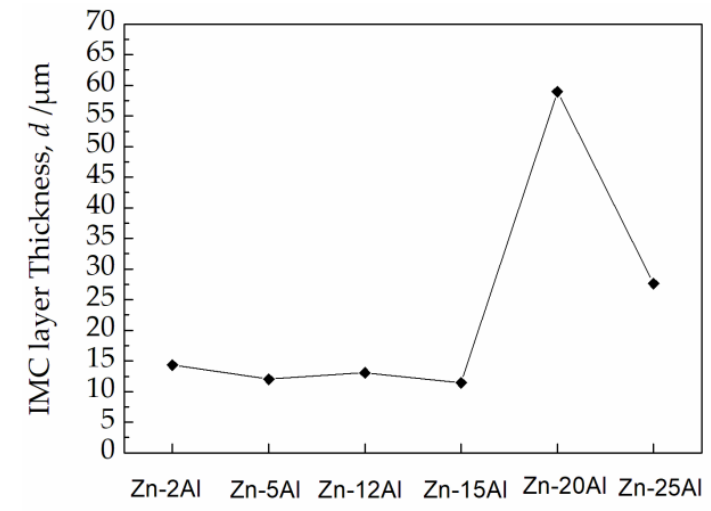

(a)

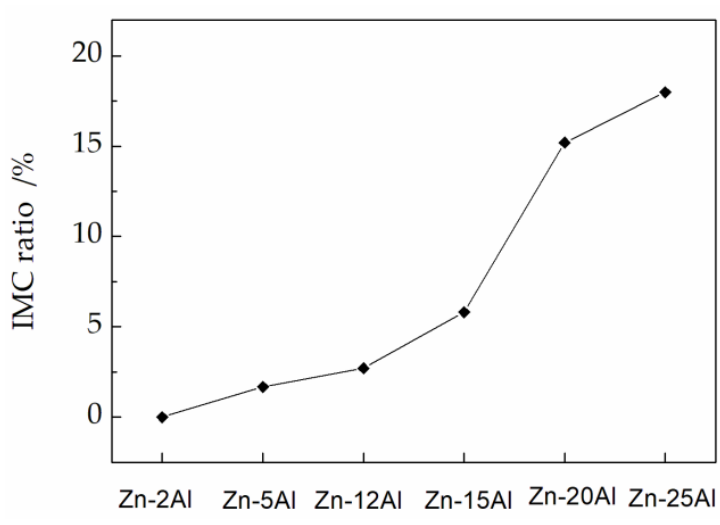

(b)

Figure 15. Changes of (a) IMC layer thickness and (b) bulk IMC ratio in Figure 13.

When the $\mathrm{Al}$ content exceeded $15 \mathrm{wt} . \%$, the IMC layer thickness became bigger and the bulk IMC ratio increased significantly. Meanwhile, the formation and growth of bulk $\mathrm{CuAl}_{2}$ was promoted due to the high $\mathrm{Al}$ atom concentration, which resulted in a coarse IMC bulk and induced stress concentration. As a consequence, the joint strength decreased. Moreover, it is noteworthy that the IMC layer thickness decreased when the $\mathrm{Al}$ content went from $20 \mathrm{wt} . \%$ to $25 \mathrm{wt} . \%$ in Figure 15. For the joint brazed by $\mathrm{Zn}-25 \mathrm{Al}$, a huge bulk $\mathrm{Cu}-\mathrm{Al} \mathrm{IMC}$ occupied a great deal of $\mathrm{Al}$ atoms and $\mathrm{Cu}$ atoms near the IMC layer, with the area reaching $2557.48 \mu \mathrm{m}^{2}$. Hence, the IMC layer thickness became thinner when compared to $\mathrm{Zn}-20 \mathrm{Al}$.

In summary, when the $\mathrm{Al}$ content of filler metals is $15 \mathrm{wt} . \%$ or less, the amount of dispersed fine $\mathrm{Cu}-\mathrm{Al} \mathrm{IMC}$ in $3003 \mathrm{Al} / \mathrm{Cu}$ joints is larger than that of $1035 \mathrm{Al} / \mathrm{Cu}$ joints. When the $\mathrm{Al}$ content of filler metals exceeds $15 \mathrm{wt} . \%$, the distribution of $\mathrm{Cu}-\mathrm{Al} \mathrm{IMC}$ bulks is more homogenous in $3003 \mathrm{Al} / \mathrm{Cu}$ joints than in $1035 \mathrm{Al} / \mathrm{Cu}$ joints. Additionally, $\mathrm{Mn}$ atoms in $3003 \mathrm{Al}$ base metals diffuse into a brazing seam and then form a solid solution with $\mathrm{Al}$ and $\mathrm{Zn}$. Because of the dissolution of $\mathrm{Mn}, 3003 \mathrm{Al} / \mathrm{Cu}$ joints possess larger lattice distortion and stronger solution strengthening. Therefore, the joint strengths of $3003 \mathrm{Al} / \mathrm{Cu}$ joints are significantly higher than that of $1035 \mathrm{Al} / \mathrm{Cu}$ joints.

\subsection{Fracture Analysis of $3003 \mathrm{Al} / \mathrm{Cu}$ Joints}

Figure 16 shows the fractography of $3003 \mathrm{Al} / \mathrm{Cu}$ joints at $\mathrm{Cu}$ side. The results show that the fracture behaviors belong to brittle fracture, as plastic deformations were not obviously caused in the course of joint fracture. For joints brazed by $\mathrm{Zn}-2 \mathrm{Al}$ and $\mathrm{Zn}-5 \mathrm{Al}$, as shown in Figure 16a,b, a cleavage surface and inter-granular fracture can be observed, indicating a mixed-mode fracture. For the joint brazed by $\mathrm{Zn}-12 \mathrm{Al}$, only the cleavage surfaces can be seen as shown in Figure 16c, which exhibits cleavage fracture. Because of the small IMC layer thickness and the proper IMC ratio in the brazing seam, it is not liable to induce stress concentration at the interface when the joint is under load. Thus, the shear strength of joint brazed by $\mathrm{Zn}-12 \mathrm{Al}$ is highest, at $94.37 \mathrm{MPa}$. Meanwhile, for joints brazed by $\mathrm{Zn}-15 \mathrm{Al}, \mathrm{Zn}-20 \mathrm{Al}$ and $\mathrm{Zn}-25 \mathrm{Al}$, the fracture exhibits a mixture of inter-granular fracture and cleavage fracture again, as shown in Figure 16d-f. When $\mathrm{Al}$ content exceeded $12 \mathrm{wt} . \%$, the bulk IMC in brazing 
seams became coarse, and the $\mathrm{CuAl}$ layer grew thick. This caused stress concentration and crack initiation, and led to a decrease of the joint strength.
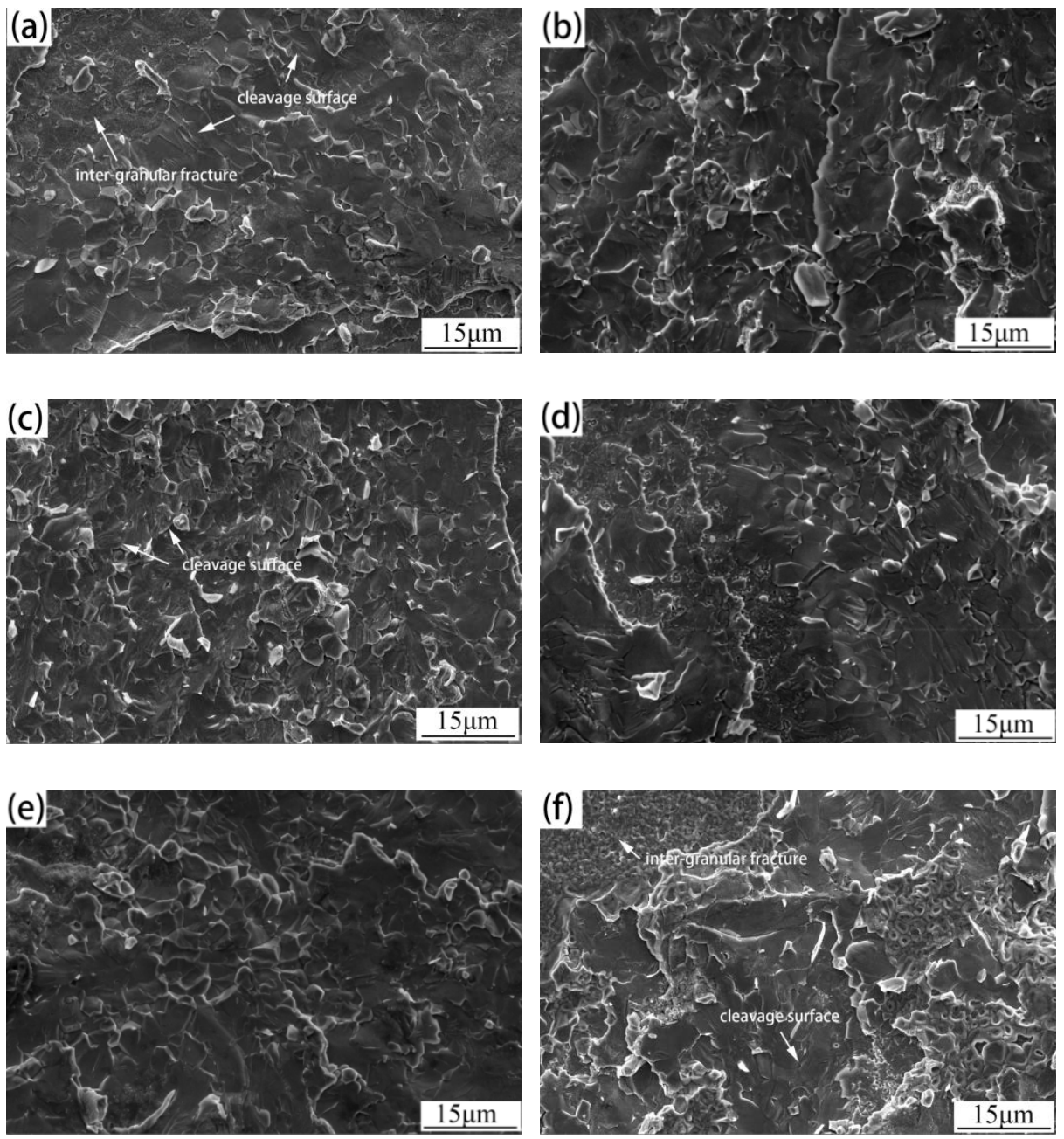

Figure 16. Fractography at the $\mathrm{Cu}$ side of $3003 \mathrm{Al} / \mathrm{Cu}$ joints brazed by: (a) $\mathrm{Zn}-2 \mathrm{Al}$; (b) $\mathrm{Zn}-5 \mathrm{Al}$; (c) Zn-12Al; (d) Zn-15Al; (e) Zn-20Al; and (f) Zn-25Al.

\subsection{Fracture Analysis of $1035 \mathrm{Al} / \mathrm{Cu}$ Joints}

Figure 17 shows the fractography of $1035 \mathrm{Al} / \mathrm{Cu}$ joints at the $\mathrm{Cu}$ side. All the fracture modes have a brittle fracture due to some plastic deformations during shear tests. The fractographies of all the brazing joints indicate inter-granular fracture. For the joints brazed by $\mathrm{Zn}-2 \mathrm{Al}, \mathrm{Zn}-5 \mathrm{Al}$ and $\mathrm{Zn}-12 \mathrm{Al}$, the bright even plane morphology can be seen, as shown in Figure $17 \mathrm{a}-\mathrm{c}$. For the joints brazed by $\mathrm{Zn}-15 \mathrm{Al}$ and $\mathrm{Zn}-20 \mathrm{Al}$, some pits caused by grain detachment from the fracture surface can be observed in Figure 17d,e. Stress concentration can hardly be induced at the interface at the $\mathrm{Cu}$ side when the joint brazed by $\mathrm{Zn}-15 \mathrm{Al}$ is under load, which benefits from the thin interfacial layer and proper IMC ratio in the brazing seam. Thus, the shear strength is the highest, at $44.04 \mathrm{MPa}$. For the joint brazed by $\mathrm{Zn}-25 \mathrm{Al}$, a large plane morphology is observed, as shown in Figure 17f. The unevenly distributed coarse bulk $\mathrm{CuAl}_{2}$ induced stress concentration and crack initiation at the interface at the $\mathrm{Cu}$ side, which reduced the joint strength. 

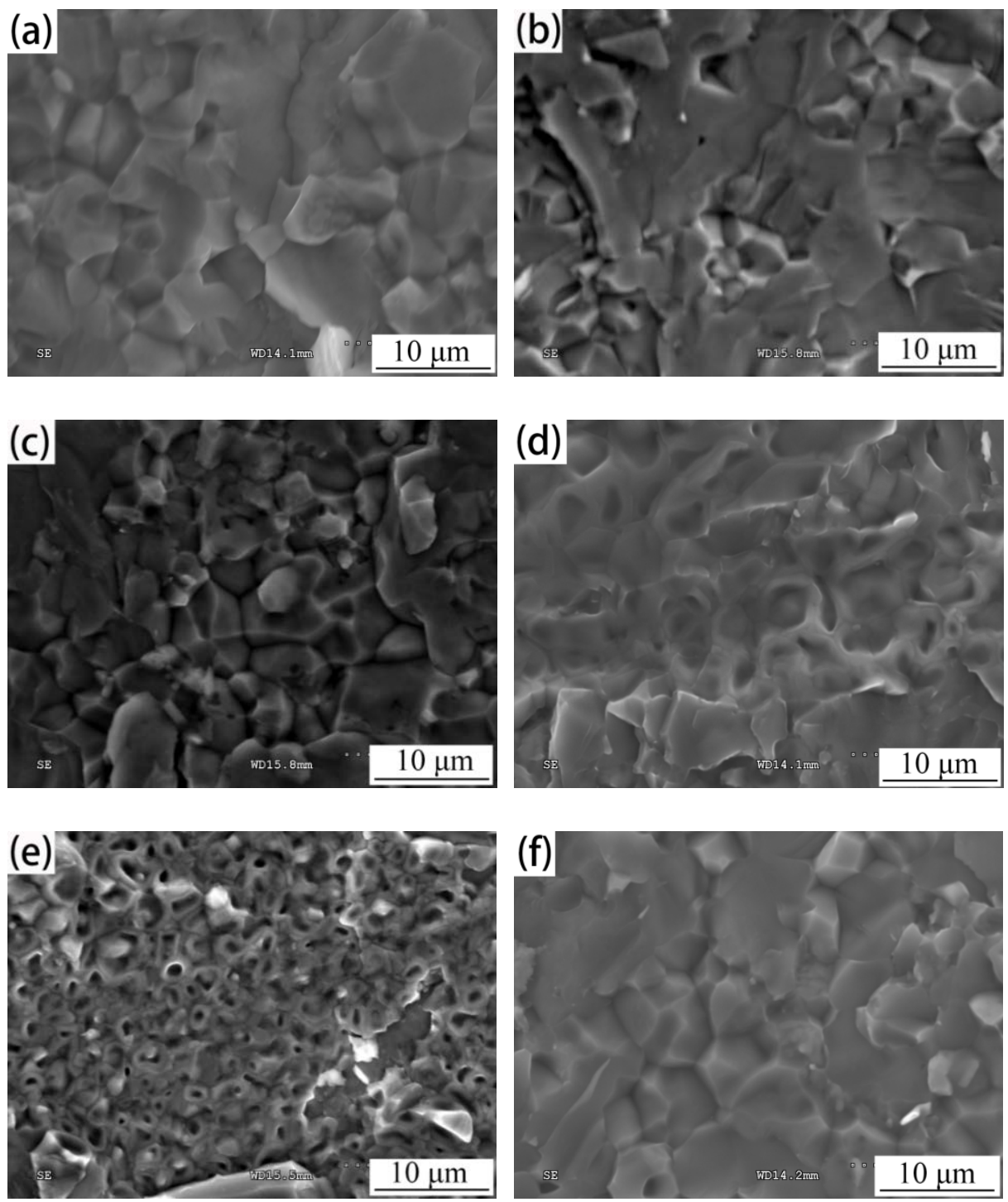

Figure 17. Fractography of at $\mathrm{Cu}$ side $1035 \mathrm{Al} / \mathrm{Cu}$ joints brazed by: (a) $\mathrm{Zn}-2 \mathrm{Al}$; (b) $\mathrm{Zn}-5 \mathrm{Al}$; (c) $\mathrm{Zn}-12 \mathrm{Al}$; (d) Zn-15Al; (e) Zn-20Al; and (f) Zn-25Al.

\section{Conclusions}

(1) Microstructure analysis showed the number of bulk IMCs at the $\mathrm{Cu}$ sides was larger than that at the $\mathrm{Al}$ sides in both $3003 \mathrm{Al} / \mathrm{Cu}$ joints and $1035 \mathrm{Al} / \mathrm{Cu}$ joints, which was caused by the higher $\mathrm{Cu}$ concentration at the brazing seam/Cu interface. Therefore, stress concentration and crack initiation were readily formed at this interface at the $\mathrm{Cu}$ side, due to the stiffness mismatch between the IMC layer and the brazing seam alloy, as well as fractures that mainly occurred at the brazing seam/IMC interface at the $\mathrm{Cu}$ sides.

(2) A CuAl IMC layer and an $\mathrm{Al}_{4.2} \mathrm{Cu}_{3.2} \mathrm{Zn}_{0.7}$ IMC layer formed at brazing seam/Cu interface in $3003 \mathrm{Al} / \mathrm{Cu}$ joints and $1035 \mathrm{Al} / \mathrm{Cu}$ joints, respectively. For $3003 \mathrm{Al} / \mathrm{Cu}$ joints, bulk $\mathrm{CuAl}$ and $\mathrm{CuAl}_{2} \mathrm{IMC}$ formed in brazing seams, while for $1035 \mathrm{Al} / \mathrm{Cu}$ joints, only bulk $\mathrm{CuAl}_{2} \mathrm{IMC}$ formed in brazing seams. The bulk IMC ratio continuously increased with the $\mathrm{Al}$ content in the filler metals, and the thinnest thicknesses of IMC layers at the brazing seam/Cu interface in $3003 \mathrm{Al} / \mathrm{Cu}$ joints and $1035 \mathrm{Al} / \mathrm{Cu}$ joints were achieved with $\mathrm{Zn}-12 \mathrm{Al}$ and $\mathrm{Zn}-15 \mathrm{Al}$, respectively.

(3) In general, the joint strength of $3003 \mathrm{Al} / \mathrm{Cu}$ joints were always higher than that of $1035 \mathrm{Al} / \mathrm{Cu}$ joints. For both $3003 \mathrm{Al} / \mathrm{Cu}$ joints and $1035 \mathrm{Al} / \mathrm{Cu}$ joints, the joint strength increased first, then decreased with the increasing $\mathrm{Al}$ content. The highest joint strength of $3003 \mathrm{Al} / \mathrm{Cu}$ joints achieved $94.37 \mathrm{MPa}$ 
by $\mathrm{Zn}-12 \mathrm{Al}$, while that of $1035 \mathrm{Al} / \mathrm{Cu}$ joints achieved $44.04 \mathrm{MPa}$ by $\mathrm{Zn}-15 \mathrm{Al}$. The increase in the joint strength is due to the dispersion strengthening of $\mathrm{Cu}-\mathrm{Al} \mathrm{IMC}$ in brazing seams, since amounts of bulk $\mathrm{Cu}-\mathrm{Al} \mathrm{IMC}$ increased with increasing $\mathrm{Al}$ content in filler metals. However, with the excessive $\mathrm{Al}$ content (beyond $12 \mathrm{wt} . \%$ for $3003 \mathrm{Al} / \mathrm{Cu}$ joints and $15 \mathrm{wt} . \%$ for $1035 \mathrm{Al} / \mathrm{Cu}$ joints), the IMC in brazing seams became coarse, and the IMC layers at brazing seam/Cu interface grew thick. Therefore, the joint strength decreased due to stress concentration.

Author Contributions: All work has been done by M.Z. All author have read and agreed to the published version of the manuscript.

Funding: This research received no external funding.

Conflicts of Interest: The authors declare no conflict of interest.

\section{References}

1. Eslami, N.; Hischer, Y.; Harms, A.; Lauterbach, D.; Böhm, S. Optimization of process parameters for friction stir welding of aluminum and copper using the Taguchi method. Metals 2019, 9, 63. [CrossRef]

2. Mubiayi, M.P.; Akinlabi, E.T. Evolving properties of friction stir spot welds between AA1060 and commercially pure copper C11000. Trans. Nonferr. Metals Soc. 2016, 26, 1852-1862. [CrossRef]

3. Ni, Z.L.; Ye, F.X. Effect of lap configuration on the microstructure and mechanical properties of dissimilar ultrasonic metal welded copper-aluminum joint. J. Mater. Process. Technol. 2017, 245, 180-192. [CrossRef]

4. Balasundaram, R.; Patel, V.K.; Bhole, S.D.; Chen, D.L. Effect of zinc interlayer on ultrasonic spot welded aluminum-to-copper joints. Mater. Sci. Eng. A 2014, 607, 277-286. [CrossRef]

5. Zhang, W.; Shen, Y.F.; Yan, Y.F.; Guo, R. Dissimilar friction stir welding of $6061 \mathrm{Al}$ to T2 pure Cu adopting tooth-shaped joint configuration: Microstructure and mechanical properties. Mater. Sci. Eng. A 2017, 690, 355-364. [CrossRef]

6. Reisgen, U.; Olschok, S.; Jakobs, S.; Holtum, N. Influence of the degree of dilution with laser beam vacuum-welded $\mathrm{Cu}-\mathrm{Al}$ mixed joints on the electrical properties. Procedia CIRP 2018, 74, 23-26. [CrossRef]

7. Zhang, J.Q.; Shen, Y.F.; Yao, X.; Xu, H.S.; Li, B. Investigation on dissimilar underwater friction stir lap welding of 6061-T6 aluminum alloy to pure copper. Mater. Des. 2014, 64, 74-80. [CrossRef]

8. Das, A.; Li, D.Z.; Williams, D.; Greenwood, D. Weldability and shear strength feasibility study for automotive electric vehicle battery tab interconnects. J. Braz. Soc. Mech. Sci. Eng. 2019, 41, 54. [CrossRef]

9. Wei, Y.N.; Li, J.L.; Xiong, J.T.; Zhang, F.S. Investigation of interdiffusion and intermetallic compounds in Al-Cu joint produced by continuous drive friction welding. Eng. Sci. Technol. Int. J. 2017, 19, 90-95. [CrossRef]

10. Zhou, X.L.; Zhang, G.; Shi, Y.; Zhu, M.; Yang, F.Q. Microstructures and mechanical behavior of aluminum-copper lap joints. Mater. Sci. Eng. A 2017, 705, 105-113. [CrossRef]

11. Das, A.; Butterworth, I.; Masters, I.; Williams, D. Microstructure and mechanical properties of gap-bridged remote laser welded (RLW) automotive grade AA 5182 joints. Mater. Charact. 2018, 145, 697-712. [CrossRef]

12. Das, A.; Masters, I.; Williams, D. Process robustness and strength analysis of multi-layered dissimilar joints using ultrasonic metal welding. Int. J. Adv. Manuf. Technol. 2019, 101, 881-900. [CrossRef]

13. Weigla, M.; Alberta, F.; Schmidt, M. Enhancing the ductility of laser-welded copper-aluminum connections by using adapted filler materials. Phys. Procedia 2011, 12, 332-338. [CrossRef]

14. Li, W.Y.; Wen, Q.; Yang, X.W.; Wang, Y.S.; Gao, D.L.; Wang, W.B. Interface microstructure evolution and mechanical properties of $\mathrm{Al} / \mathrm{Cu}$ bimetallic tubes fabricated by a novel friction-based welding technology. Mater. Des. 2017, 134, 383-393. [CrossRef]

15. Tan, C.W.; Jiang, Z.G.; Li, L.Q.; Chen, Y.B.; Chen, X.Y. Microstructural evolution and mechanical properties of dissimilar Al-Cu joints produced by friction stir welding. Mater. Des. 2013, 51, 466-473.

16. Eslami, N.; Hischer, Y.; Harms, A.; Lauterbach, D.; Böhm, S. Influence of copper-sided tin coating on the weldability and formation of friction stir welded aluminum-copper-joints. Metals 2019, 9, 179. [CrossRef]

17. Satpathya, M.P.; Sahoob, S.K. Mechanical performance and metallurgical characterization of ultrasonically welded dissimilar joints. J. Manuf. Process. 2017, 25, 443-451. [CrossRef] 
18. Shiran, M.K.G.; Khalaj, G.; Pouraliakbar, H.; Jandaghi, M.R.; Dehnavi, A.S.; Bakhtiari, H. Multilayer Cu/Al/Cu explosive welded joints: Characterizing heat treatment effect on the interface microstructure and mechanical properties. J. Manuf. Process. 2018, 35, 657-663. [CrossRef]

19. Zhang, Y.; Li, Y.; Luo, Z.; Yuan, T.; Bi, J.; Wang, Z.M.; Wang, Z.P.; Chao, Y.J. Feasibility study of dissimilar joining of aluminum alloy 5052 to pure copper via thermo-compensated resistance spot welding. Mater. Des. 2016, 106, 235-246. [CrossRef]

20. Wang, X.G.; Li, X.G.; Wang, C.G. Influence of diffusion brazing parameters on microstructure and properties of $\mathrm{Cu} / \mathrm{Al}$ joints. J. Manuf. Process. 2018, 35, 343-350. [CrossRef]

21. Xia, C.Z.; Li, Y.J.; Puchkov, U.A.; Gerasimov, S.A.; Wang, J. Microstructure and phase constitution near the interface of $\mathrm{Cu} / \mathrm{Al}$ vacuum brazing using Al-Si filler metal. Vacuum 2008, 82, 799-804. [CrossRef]

22. Huang, M.L.; Huang, Y.Z.; Ma, H.T.; Zhao, J. Mechanical properties and electrochemical corrosion behavior of Al/Sn-9Zn-xAg/Cu joints. J. Electron. Mater. 2011, 40, 315-323. [CrossRef]

23. Niu, Z.W.; Ye, Z.; Huang, J.H.; Yang, H.; Yang, J.; Chen, S.H. Interfacial structure and properties of Cu/Al joints brazed with Zn-Al filler metals. Mater. Charact. 2018, 138, 78-88. [CrossRef]

24. Ji, F.; Xue, S.B.; Dai, W. Effects of Ti on the Brazability of Zn-22AI-xTi Filler Metals as Well as Properties of $\mathrm{Cu} / \mathrm{Al}$ Brazing Joints. Rare Metal Mater. Eng. 2013, 42, 2453-2457.

25. Ji, F.; Xue, S.B. Growth behaviors of intermetallic compound layers in $\mathrm{Cu} / \mathrm{Al}$ joints brazed with $\mathrm{Zn}-22 \mathrm{Al}$ and Zn-22Al-0.05Ce filler metals. Mater. Des. 2013, 51, 907-915.

26. Xiao, Y.; Ji, H.J.; Li, M.Y.; Kim, J. Ultrasound-assisted brazing of Cu/Al dissimilar metals using a Zn-3Al filler metal. Mater. Des. 2013, 52, 740-747. [CrossRef]

27. Zhang, H.W.; Cui, W.; He, J.S.; Yan, J.C.; Yang, S.Q. Formation and evolution of intermetallic compounds at interfaces of $\mathrm{Cu} / \mathrm{Al}$ joints by ultrasonic-assisted soldering. J. Mater. Process. Technol. 2015, 223, 1-7.

28. Ye, Z.; Yang, H.; Huang, J.H.; Yang, J.; Chen, S.H. A novel Zn-Al-Si corrosion resistant filler metal for Cu/Al brazing. Mater. Lett. 2017, 206, 201-204. [CrossRef]

29. Liu, G.P.; Hu, X.W.; Fu, Y.S.; Li, Y.L. Microstructure and mechanical properties of ultrasonic welded joint of 1060 aluminum alloy and T2 pure copper. Metals 2017, 7, 361. [CrossRef]

30. Solchenbach, T.; Plapper, P. Mechanical characteristics of laser braze-welded aluminium-copper connections. Opt. Laser Technol. 2013, 54, 249-256. [CrossRef]

31. Zhang, Q.Y.; Zhuang, H.S. Brazing and Soldering Manual, 2nd ed.; China Machine Press: Beijing, China, 2005; pp. 66-120.

32. Wang, Z.Z. Material Science Foundation, 1st ed.; China Machine Press: Beijing, China, 2005; p. 51.

33. Wuhan University; Jilin University. Inorganic Chemistry, 3rd ed.; Higher Education Press: Beijing, China, 1994; p. 106.

(C) 2020 by the author. Licensee MDPI, Basel, Switzerland. This article is an open access article distributed under the terms and conditions of the Creative Commons Attribution (CC BY) license (http://creativecommons.org/licenses/by/4.0/). 